\title{
The source of the problem
}

\author{
When Rivers Run Dry: Water - The \\ Defining Crisis of the Twenty-First Century \\ by Fred Pearce \\ Eden Books/Beacon Press: 2006. 368 pp. \\ $£ 18.99 / \$ 26.95$
}

\section{Ganesh Pangare}

A global water shortage is set to be the major crisis of the twenty-first century, so of course a vast amount has been written about it, both in the popular media and in academic books and journals. What is unique about When Rivers Run Dryby journalist Fred Pearce is the style and presentation of the facts and events that explain the causes and scale of the problem. Pearce's anecdotal style and the personal accounts of the people he met during his travels make it highly readable.

Pearce takes the reader on a journey around the world exploring the worst water-related disasters, They have occurred not only in the developing world, but also in countries that on the face of it seem to have their water problems under control. How many of us are aware that the once mighty Rio Grande has been reduced to a trickle near the US-Mexican border? Or that Libya's network of pipes known as the Great Manmade River can carry $6,500,000 \mathrm{~m}^{3}$ of water every year across 600 miles of desert? Or that Saudi Arabia grew all its wheat, and now grows its alfalfa, using very old, irreplaceable 'fossil water' from ancient aquifers? Or that the groundwater used by China, India and Pakistan is estimated to be more than half of the total used by the whole world? Or that in California, $15 \%$ more water is being pumped out than is being replenished?

If the author's intention is to shock the reader with these facts, he succeeds. However, the book tends to look more at the problems and less at the proposed solutions. Also, some of the stories - such as that of the Indian farmer who uses groundwater to grow alfalfa to feed his cattle and is part of a flourishing dairy industry — need to be viewed not only in the context of the water problem, but within the context of the larger socio-economic problems in the region. Nevertheless, despite focusing solely on water, the book contains much to appreciate.

Its value lies in the way it makes such a serious subject interesting and informative both for lay readers and water professionals. It looks at the complete spectrum of the social, political and economic complexity of water, covering issues related to surface water (rivers, lakes and wetlands), groundwater exploitation and quality, conflicts related to water, transboundary waters, floods and droughts. Crucially, many of these are viewed through the eyes of local people who are directly affected by these issues.

Interspersed in the text are large amounts

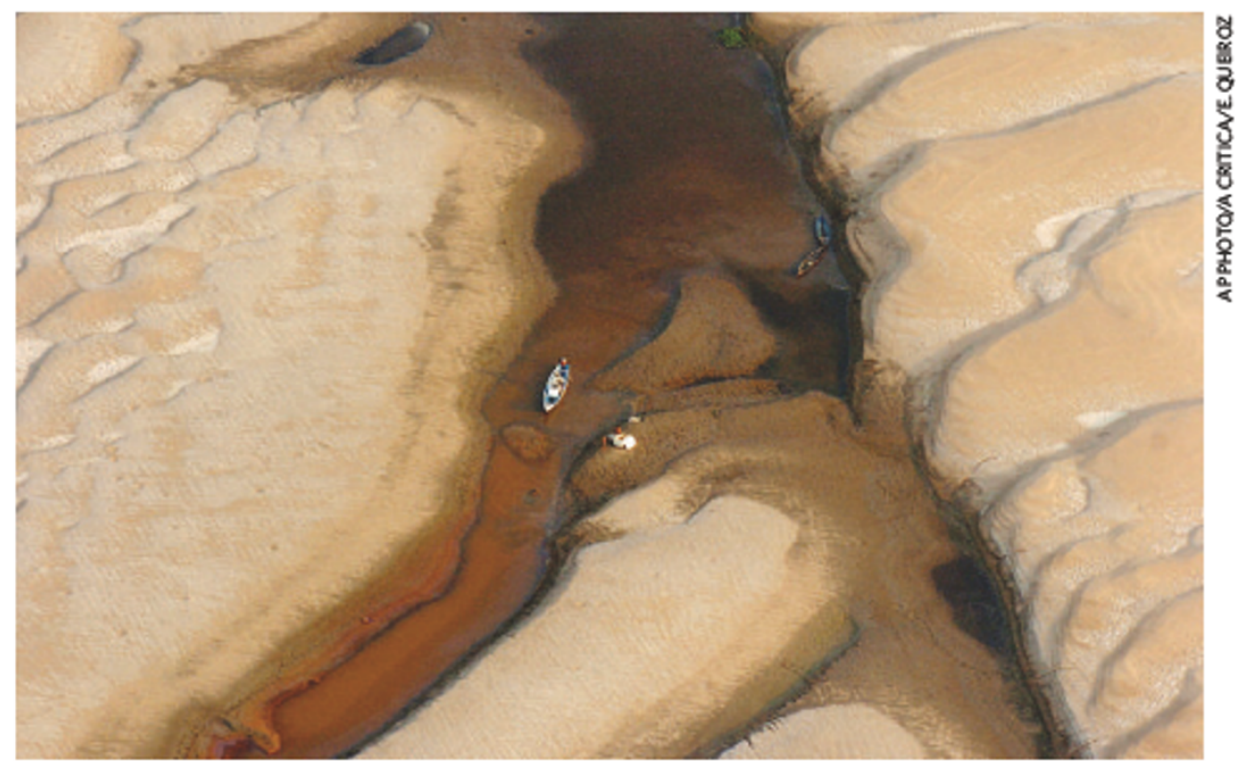

Alldried out: a boat tries to negotiate what remains of a section of the Amazon River in Brazil.

of data, but they are explained in a way that makes them easy to grasp. For example, figures for water consumption and use are defined in the context of our daily routine and activities, such as the amount of water required to grow various foods, where this water comes from, and whose water we are taking when we consume these foods. Comparisons between the way countries use and consume water are made in a similar manner. These facts are also used to explain the politics and economics of 'blue' water (found on the surface) and 'green' water (stored as soil moisture and hence available to plants), as well as the import and export of virtual water, concepts that previously remained in the domain of water professionals and academics.

Rivers are sacred to religions, symbols of nationhood, and givers of life. We need water to survive, today and in the future. The desire to meet today's needs has always influenced the way we deal with water and forced us to overcome our desire to save some for future use. But this must change or there will soon be almost none left for tomorrow, and this is the book's central message. We need to save our rivers. We need to find ways of "storing water without wrecking the environment, of restoring water to rivers, and refilling lakes and wetlands", and of sharing waters rather than fighting over them. "It requires us to go with the flow. And to do so before the rivers finally run dry."

Ganesh Pangare is director of the World Water Institute, 6 Pentium Classic Apartments, NDA-Pashan Road, Bavdhan, Pune 411021, India.

\section{A martian mystery}

\section{The Rock from Mars: A Detective Story on Two Planets \\ by Kathy Sawyer \\ Random House: 2006. 416 pp. $\$ 25.95$}

\section{John F. Kerridge}

Discovering life beyond Earth will change forever our view of the Universe and our place within it. So when a team led by David McKay of NASA's Johnson Space Center announced in August 1996 that they had found evidence for ancient life in a martian meteorite (D. S. McKay et al. Science 273, 924-930; 1996), the world sat up and took notice. How that announcement came to pass and what happened afterwards form the subject matter of The Rock From Mars.
Kathy Sawyer, a journalist formerly with The Washington Post, has produced a model of science writing for the general public. She gets the science right (with an occasional bobble), she reports with commendable balance on the intense controversy generated by McKay and colleagues' announcement, and her lucid writing should prove largely comprehensible to non-scientists. She accurately depicts the day-to-day life of the scientists involved and brings out how their observations and ideas are processed by the scientific community as it gropes its way towards the truth.

McKay's team got one thing dead right: if you want the scientific community to believe you've found evidence for extraterrestrial life, 
you should provide several independent lines of evidence, something Sawyer terms a 'holistic' approach. The lines of evidence they use are termed 'biosignatures'. The critical feature of a biosignature is not that it can be produced by biological activity, but that it cannot be produced non-biologically. Evaluation of McKay and colleagues' claim therefore rested on whether their lines of evidence were really biosignatures, or whether they could have been produced non-biologically.

Their observations of meteorite ALH84001 (which is firmly established as martian even though it was found in Antarctica) led McKay and colleagues to advance four potential biosignatures. Two of them - the presence of organic matter and ultra-small fossil-like forms - were quickly rebuffed. The organic matter, although partly of apparently martian origin (itself a notable achievement by the team), consisted of polycyclic aromatic hydrocarbons, which are not plausible biosignatures as they can easily be made by non-biological processes. The 'fossils' could not be reliably distinguished from textures intrinsic to their mineral hosts, which had not previously been studied at such high magnification. That left two candidate biosignatures: unusual layered globules of carbonate, and, contained within them, tiny magnetite crystals that closely resembled those in magnetotactic bacteria on Earth.

Towards the end of chapter 13, Sawyer cites several studies that "soon challenged the biological scenario anew". But then the chapter winds down without further reference to these studies, two of which turn out to be particularly important (they are briefly described in the notes). In the final two chapters, Sawyer shifts gears twice, once to discuss a marginally related controversy, and finally to report on some recent missions to Mars. Both chapters would have made interesting appendices to the book, but the claim made by McKay and colleagues is left hanging in limbo; the "detective story" ends not with a bang but a whimper. This is particularly unfortunate as the two studies mentioned above would have provided the bang of two smoking guns.

First, a team from the Johnson Space Center led by Gordon McKay, David's brother, succeeded in synthesizing identical layered carbonate globules in the absence of biological activity, thereby destroying the globules' status as a plausible biosignature (D. C. Golden et al. Am. Mineral. 86, 370-375; 2001). Second, a study by David Barber and Ed Scott (Proc. Natl Acad. Sci. USA 99, 6556-6561;2002) drove the final nail into the coffin. They showed that the crystal lattices of the ultrafine magnetites within the meteorite's carbonates were topotactically related to that of the carbonate host, a point that I had made in 1999 , based on findings by John Bradley and co-workers (Meteorit. Planet. Sci. 33, 765-774; 1998). Note that this is a true three-dimensional relationship, as first observed synthetically by J. D. Bernal and co-workers (Clay Mineral. Bull. 4, 15-30; 1959); it should not be confused with epitaxy, a twodimensional relationship. It means that the magnetites must have formed directly by decomposition of carbonate, and could not plausibly be bacterial in origin. Barring an extraordinary coincidence, this conclusion must apply to all the nanoscale magnetites in the carbonate.

Even though I would have liked the book to conclude with closure of this tumultuous episode, this is nonetheless an outstanding popularization of science that deserves to be widely read, not least by those interested in the 'logic of scientific discovery'.

Finally, it is worth noting that, despite the demise of the biosignatures proposed by McKay and co-workers, the search for evidence of ancient life on Mars remains scientifically reasonable and, indeed, of fundamental importance.

John F. Kerridge is at 334 El Amigo Road, Del Mar, California 92014, USA.

\section{A search for meaning}

\section{The Happiness Hypothesis: Finding \\ Modern Truth in Ancient Wisdom \\ by Jonathan Haidt \\ Basic Books: 2005.320 pp. $€ 34.95, £ 15.50$ \\ To be published in Britain in August by \\ William Heinemann.}

\section{Daniel Nettle}

There is a striking similarity between the advice of the ancients on how to live, and the thoughts of modern psychologists on how to have a healthy mind. The Roman emperor Marcus Aurelius' dictum that life "is but what you deem it ${ }^{\prime}$ resonates with modern research on the importance of thinking styles in coping with stress and adversity; and the Buddha's teachings on non-attachment seem to prefigure the ideas of modern cognitive therapies. The ancients, it seems, were good psychologists and understood, in an observational and intuitive way, how the mind works.

Jonathan Haidt takes this insight seriously in his new book The Happiness Hypothesis. The subtitle is a much better description of the fare on offer than the main title, as he takes the condusions of classical philosophers and thinkers on ten enduringly important themes and considers their conclusions alongside the findings of modern psychology. The ten subject areas are: the idea that the mind is made up of several often-conflicting drives or mechanisms; the idea that how we think about the world is more important than how the world actually is; the importance of reciprocity in social life; the biases that blind us to our own shortcomings but not to shortcomings in others; the paradoxical nature of pursuing happiness; the importance of love; the strengthening power of adversity; the importance of virtue, in its broadest sense; the power of spirituality; and finally, the importance of coherence in life. Haidt draws principally from Greek and Roman philosophy, from Indian and Chinese traditions, as well as a peppering of

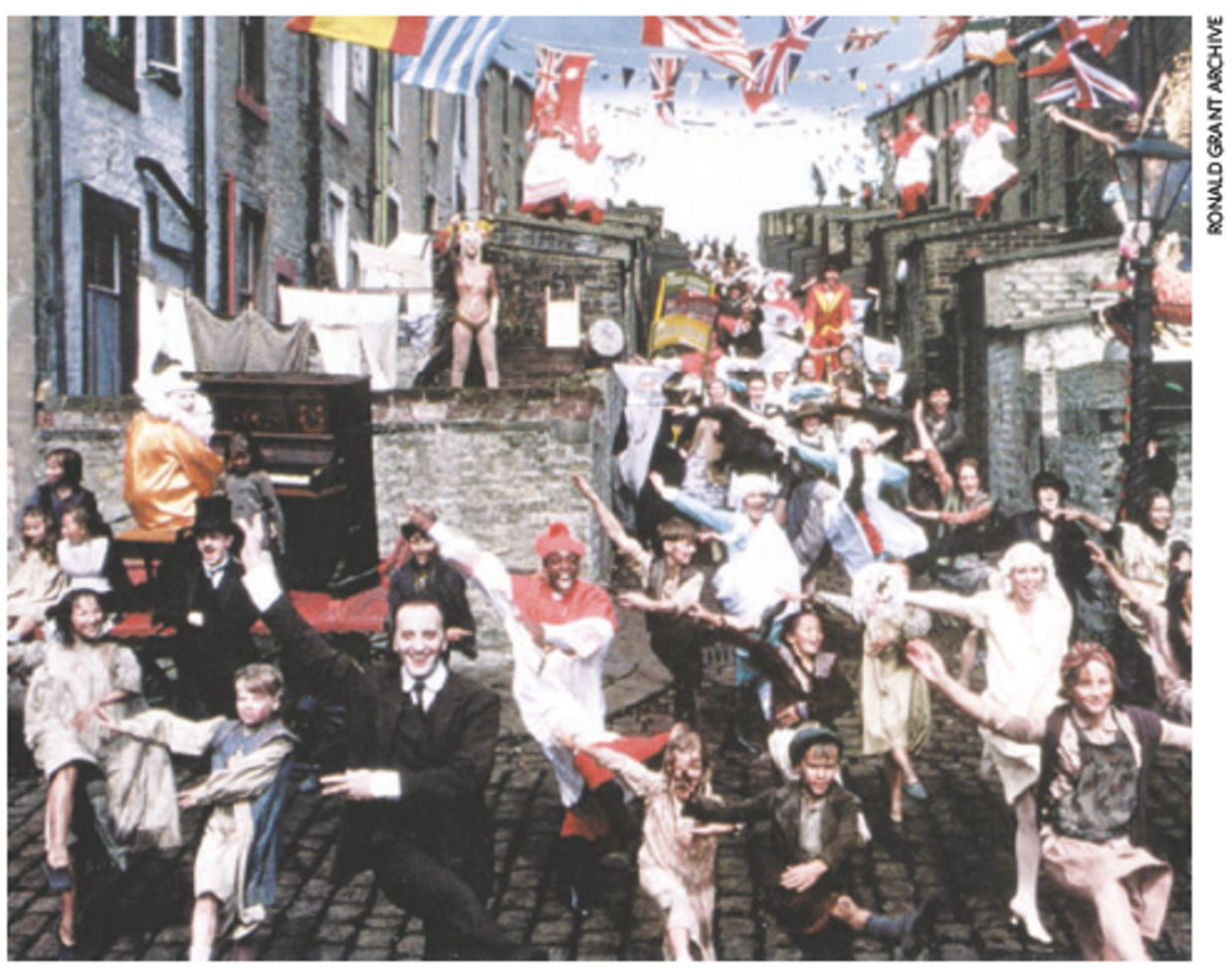

What does it all mean? Monty Python's The Meaning of Life may not have been far from the truth.

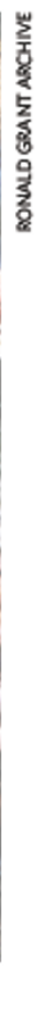

